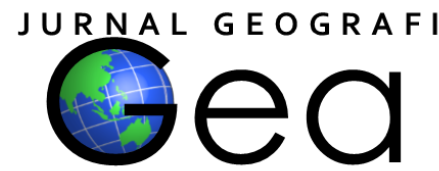

\title{
PERKEMBANGAN SARANA DAN PRASARANA TRANSPORTASI DALAM HUBUNGANNYA DENGAN TINGKAT PEREKONOMIAN MASYARAKAT DI DESA KOLANG KECAMATAN KUWUS BARAT, KABUPATEN MANGGARAI BARAT, PROVINSI NUSA TENGGARA TIMUR

\author{
Rikardus Kristiano ${ }^{1}$, Suryana $^{2}$, Upi Supriatna ${ }^{3}$ \\ ${ }^{1,2,3}$ Program Studi Pendidikan Geografi Universitas Bale Bandung \\ ${ }^{1}$ rikarduskristiano5@gmail.com, ${ }^{2}$ Suryanas358@gmail.com, ${ }^{3}$ upisupriatna80@gmail.com.
}

\section{ABSTRACT}

The development of transportation facilities and infrastructure is very important in supporting the success of development, especially in supporting the economic activities of the community and in increasing regional development both in rural and urban areas. The purpose of this research is to find out how the development of transportation facilities and infrastructure and how they relate to the economy of the community in Kolang Village, West Kuwus Barat, West Manggarai Barat, East Nusa Tenggara Timur. The method used in this research is descriptive research method. which is a research method in examining the status of a group of people an object, a system of thought, a set of conditions, or a class of events in the current period. As for the data collection techniques using interview, observation, questionnaires and documentation. while the population is $230 \mathrm{kk}$ with a total sampel of $47 \mathrm{kk}$, and from the 47 sampels taken randomly. The results of this study indicate that transportation facilities and infrastructure that are not good will affect the economic level, the level of education in an area, especially in the village of Kolang with a level of influence on economic income reaching $47 \%$.

Keywords: Development, Transportation Facilities, Infrastructure, Economy.

\begin{abstract}
ABSTRAK
Perkembangan sarana dan prasarana transportasi merupakan komponen sangat penting dalam menunjang keberhasilan pembangunan terutama dalam mendukung kegiatan perekonomian masyarakat dan meningkatkan pengembangan wilayah baik di daerah pedesaan maupun daerah perkotaan. Tujuan dalam penelitian ini yaitu untuk mengetahui bagaimana perkembangan sarana dan prasarana transportasi serta hubunganya dengan perekonomian masyarakat di Desa Kolang, Kecamatan Kuwus Barat, Kabupaten Manggarai Barat Provinsi Nusa Tenggara Timur. Metode yang digunakan dalam penelitian ini menggunakan metode penelitian deskriptif yang merupakan suatu metode penelitian dalam meneliti setatus dari sekelompok manusia, suatu obyek, suatu sistem pemikiran, suatu set kondisi, ataupun suatu kelas peristiwa pada masa saat ini. Sedangkan untuk teknik pengumpulan datanya mengunakan teknik wawancara, observasi, angket dan dokumentasi. sementara untuk populasi berjumlah $230 \mathrm{kk}$, sampel dengan jumlah $47 \mathrm{kk}$, dan dari 47 sampel tersebut di ambil secara random.Hasil penelitian ini menunjukan bahwa sarana dan prasarana transportasi yang kurang baik akan berpengaruh terhadap tingkat ekonomi, tingkat pendidikan di suatu wilayah, khususnya di Desa Kolang dengan tingkat pengaruhnya terhadap pendapatan ekonomi mencapai $47 \%$.
\end{abstract}

Kata Kunci: Perkembangan, Sarana dan Prasarana Transpotasi, Ekonomi 


\section{PENDAHULUAN}

Jalan adalah prasarana transportasi darat yang meliputi segala bagian jalan, termasuk bangunan pelengkap dan perlengkapannya yang diperuntukkan bagi lalu lintas. Jalan merupakan prasarana transportasi yang sangat penting untuk mendukung arus pergerakan manusia dan barang. Tanpa jalan, aktivitas sosial dan ekonomi masyarakat akan terhambat.

Pembangunan Perasarana jalan juga merupakan sarana untuk membuka keterisoliran penduduk desa. Demikian juga dengan penduduk yang berada di Desa Kolang, Kecamatan Kuwus Barat, Kabupaten Manggarai Barat, Provinsi Nusata Tenggara Timur hingga saat ini ketersediaan infrastruknya masih belum dibenari sehingga akses untuk masuk maupun keluar cukup sulit untuk dilalui.

Pembangunan infrastruktur sangat berperan penting dalam mendorong pertumbuhan ekonomi, sebaliknya pertumbuhan ekonomi sendiri juga dapat menjadi tekanan bagi infrastruktur. Infrastruktur dapat membantu memajukan suatu daerah yang dikatakan terisolasi, selain itu infrastruktur akan memberi banyak manfaat bagi masyarakat desa. Pembangunan infrastruktur yang berjalan dan terencana diharapkan dapat mendorong pertumbuhan ekonomi daerah.

Kajian teori ekonomi pembangunan menjelaskan bahwa untuk menciptakan dan meningkatkan kegiatan ekonomi diperlukan sarana infrastruktur yang memadai. Infrastruktur juga merupakan segala sesuatu penunjang utama terselenggaranya suatu proses pembangunan suatu daerah. Peningkatan kebutuhan pembangunan infrastruktur berfungsi untuk mendukung pertumbuhan ekonomi yang telah mengantar pemerintah indonesia untuk menyediahkan kerangka kerja lebih baik, sehingga dapat menarik investasi dan partisipasi swasta di skala yang terukur dalam proyek infrastruktur. Infrastruktur jalan berpengaruh terhadap kemajuan pembangunan perekonomian, karena jalan merupakan kebutuhan utama masyarakat untuk melakukan mobilisasi, dengan kata lain jalan merupakan infrastruktur vital pembangunan ekonomi bagi masyarakat.

Permasalahan yang dihadapi masyarakat desa dalam pengembangan ekonomi wilayah tertinggal dipengaruhi oleh keterbatasan akses jalan dipengaruhi rusak atau memang tidak ada, sehingga cukup sulit untuk menghubungkan wilayah desa tertinggal dengan wilayah yang relatif maju. Di wilayah Nusa Tenggara Timur misalnya, masih banyak akses jalan yang sulit untuk dilalui karena rusak parah, sehingga untuk kelancaran mobilitas penduduk, barang maupun jasa cukup sulit. Seperti yang kita lihat pada tabel 1 .

Dari tabel 1 bisa dilihat bahwa pada umumnya di Manggarai Barat tidak begitu banyak sarana infrastrukutur yang ada, juga tidak adanya perhatian dari pemerintah

Tabel 1. Kondisi jalan Kabupaten Manggarai Barat

\begin{tabular}{ccccc}
\hline \multicolumn{5}{c}{ Panjang Jalan Provinsi Menurut Kabupaten Di Manggarai Barat (km,) 2013-2016 } \\
\hline \multicolumn{5}{l}{ Length Of Profincial Road By Road Condition in Manggarai Barat Regenci (km). } \\
& $\mathbf{2 0 1 3 - 2 0 1 6}$ & & & \\
\hline Kondisi Jalan & 2013 & 2014 & 2015 & 2016 \\
\hline Road Condition & & & & \\
\hline Baik/Good & 28,4 & 54,4 & 56,06 & 45.00 \\
\hline Sedang/Torelable & 120,05 & 66,2 & 34,21 & 32,2 \\
\hline Rusak/Damaged & 10,6 & 18,2 & 20,38 & 31 \\
\hline $\begin{array}{c}\text { Rusak Berat/Severely } \\
\text { Damage }\end{array}$ & - & - & 21,3 & 31,6 \\
\hline Jumlah/Total & 159,05 & 138,8 & 131,95 & \\
\hline & Sumber: Dinas Pekerjaan Umum Kabupaten Manggarai Barat
\end{tabular}


setempat terhadap infrastruktur yang rusak. Seperti di Desa Kolang KecamatanKuwus barat Kabupaten Manggarai Barat. Kondisi jalan yang merupakan akses utama sudah sekian lama belum direhabilitasi, aspal jalan yang dulunya hitam mengkilap kini termakan umur meninggalkan lapisan tanah, sehingga sarana transportasi yang masuk ke daerah ini sangat minim. Transportasi yang masuk merupakan jenis transportasi besar. Biaya transportasi untuk masuk ke Desa Kolang cukup mahal dikarenakan kondisi jalan dan ketersedian sarana transportasi yang kurang memadai. Kondisi ini tentunya tidak baik dan membuat penduduk kesulitan untuk datang dan pergi ke Desa Kolang, lebih jauh lagi akan berpengaruh terhadap perekonomian desa.

Berdasarkan uraian diatas maka penelitian ini memiliki tujuan: (1) Menganalisis perkembangan sarana dan prasarana transportasi di Desa Kolang, Kecamatan Kuwus, Kabupaten Manggarai Barat Provinsi Nusa Tenggara Timur; (2) Mengidentifikasi faktor yang mempengaruhi rusaknya kondisi jalan di Desa Kolang, Kecamatan Kuwus, Kabupaten Manggarai Barat Provinsi Nusa Tenggara Timur; (3) Menganalisis pengaruh sarana dan prasarana transportasi desa terhadap aktivitas perekonomian masyarakat Desa Kolang Kecamatan Kuwus Barat Kabupaten Manggarai Barat Provinsi Nusa Tenggara.

\section{Kajian Pustaka}

Sarana adalah barang atau benda bergerak yang dapat dipakai sebagai alat dalam pelaksanaan tugas dan fungsi unit kerja. Masyarakat pelaku perjalan (konsumen jasa transportasi) dapat di kelompokan kedalam dua kelompok (Miro 2008, hlm 18):

1. Golongan paksawaan (captive) merupakan jumlah terbesar di negara berkembang, yaitu golongan masyarakat yang terpaksa menggunakan angkutan umum karena ketiadaan mobil pribadi. Mereka secara ekonomi adalah golongan masyarakat lapisan menengah kebawah (miskin atau ekonomi lemah).

2. Golongan piliwan (choice), merupakan jumlah terbanyak di negara-negara maju, yaitu golongan masyarakat yang mempunyai kemudahan (akses) kekendaraan pribadi dan dapat memilih untuk menggunakan angkutan umum atau angkutan pribadi. Mereka secara ekonomis adalah golongan masyarakat lapisan menengah keatas (kaya atau ekonomi kuat).

Prasarana adalah barang atau benda tidak bergerak yang dapat menunjang atau mendukung pelaksanaan tugas dan fungsi unit kerja. Jalan dan jembatan adalah prasarana transportsi darat yang meliputi segala bagian jalan, termasuk bangunan pelengkap dan perlengkapannya yang diperuntukan bagi lalu lintas. Jalan merupakan prasarana yang sangat penting sebagai penunjang transportasi, dimana jalan merupakan wahana tempat terjadinya gerakan transportasi sehingga terjalin hubungan antara satu daerah dengan daerah lain. Pengertian jalan adalah salah satu ruang dimana gerakan transportasi dapat terjadi (morlok, $1998 \mathrm{hlm} \mathrm{4)}$

Transportasi merupakan dasar untuk perkembangan ekonomi dan perkembangan masyarakat serta industrialisasi. Adanya transportasi dimasyarakat menyebabkan adanya spesialisasi atau pembagian pekerjaan menurut keahlian sesuai budaya adat istiadat dan budaya suatu bangsa atau daerah.

Pertumbuhan ekonomi suatu bangsa tergantung pada tersedianya pengangkutan dalam suatu negara. Suatu barang atau komoditi mempunyai nilai menurut tempat dan waktu, jika barang tersebut dipindahkan dari suatu tempat ketempat lain. Nilai yang di berikan oleh transportasi adalah berupa nilai tempat (place utility) dan nilai waktu (timi utility). Kedua nilai tersebut di peroleh jika barang telah diangkut ketempat di mana nilainya menjadi lebih tinggi dan dapat dimanfaatkan tepat pada waktunya.

Sarana dan prasarana transportasi desa akan sangat mempengaruhi berbagai macam usaha ekonomi, fasilitas pendidikan, kesehatan, usaha pertanian dan peternakan, dan baerbagai macam usaha kegiatan lainya. Adanya sarana dan

prasarana transportasi, masyarakat akan lebih mudah bertemu dengan masyarakat di desa lain, seperti parat pemerintah di 
kecamatan dan kabupaten, pendamping desa ataupun petugas dari instasi lain. Sarana dan prasarana transportasi dapat dimanfaatkan oleh pejalan kaki dan sarana transportasi desa, seperti kendaraan pribadi dan kendaraan umum. Sarana dan prasarana transportasi akan bermanfaat jangka panjang asalkan di desain dengan baik dan dibangun dengan kualitas baik.

\section{METODE PENELITIAN}

Metode yang digunakan dalam penelitian ini menggunakan metode penelitian deskriptif. Metode penelitian deskriptif merupakan suatu metode penelitian dalam meneliti status dari sekelompok manusia, suatu obyek, suatu sistem pemikiran, suatu set kondisi, ataupun suatu kelas peristiwa pada masa saat ini (Sugiyono, 2015 hlm21). Adapun tujuan dari penelitian deskriptif ini yaitu membuat gambaran, deskripsi, atau lukisan secara sistematis, faktual dan akurat mengenai fakta, sifat serta hubungan antar fenomena yang sedang diselidiki.

Populasi dalam penelitian ini adalah masyarakat Desa Kolang Kecamatan Kuwus Barat Kabupaten Manggarai Barat Provinsi Nusa Tenggara Timur. Populasi manusia sebanyak 1.238 orang terbagi 230 kepala keluarga; 602 orang laki-laki dan 636 orang perempuan.

Tabel 2. Populasi Penelitian

\begin{tabular}{llllll}
\hline \multirow{2}{*}{ No } & \multirow{2}{*}{ RW } & \multicolumn{4}{c}{ Penduduk } \\
\cline { 3 - 6 } & & Pria & Wanita & Jumlah & KK \\
\hline 1 & 1 & 107 & 127 & 234 & 46 \\
\hline 2 & 2 & 74 & 78 & 152 & 28 \\
\hline 3 & 3 & 38 & 43 & 81 & 15 \\
\hline 4 & 4 & 55 & 42 & 97 & 15 \\
\hline 5 & 5 & 41 & 43 & 84 & 16 \\
\hline 6 & 6 & 81 & 85 & 166 & 31 \\
\hline 7 & 7 & 67 & 71 & 138 & 26 \\
\hline 8 & 8 & 80 & 85 & 165 & 31 \\
\hline 9 & 9 & 59 & 62 & 121 & 23 \\
\hline & & 602 & 636 & 1238 & 230 \\
\hline
\end{tabular}

Sampel harus dilihat sebagai suatu pendugaan terhadap populasi dan bukan dari populasi itu sendiri (Bailey, 1994 hlm 104). Mengingat luasnya Desa Kolang Kecamatan
Kuwus Barat Kabupaten Manggarai Barat Provinsi Nusa Tenggara Timur, penulis menentukan sampel dengan menggunakan sampel acak sederhana Sampel Random Sampling. Teknik Sampel Random Sampling (acak) adalah teknik pengambilan sampel dari anggota populasi yang dilakukan secara acak tanpa memperhatikan strata yang ada dalam populasi itu (Sugiyono, $2001 \mathrm{hlm}$ 57). Pengambilan sampel dalam penelitian ini dengan cara mengelompokkan ke $9 \mathrm{RW}$ yang ada menjadi 3 kelompok, dengan rincian :

1) Dilihat dari keberadaan jalan

2) Dilihat dari jumlah kepala keluarga

3) Dilihat dari luas RW

Adapun tabel sampel penelitian yaitu sebagai berikut :

Tabel 3.Sampel Penelitian

\begin{tabular}{cc}
\hline Nama RW & Jumlah KK \\
\hline Kolang 3 & $15 \mathrm{KK}$ \\
\hline Lenga 5 & $16 \mathrm{KK}$ \\
\hline Ndong 3 & $23 \mathrm{KK}$ \\
\hline Jumlah KK & $54 \mathrm{KK}$ \\
\hline
\end{tabular}

Untuk sampel manusia, penulis mengambil jumlah populasi yang terdapat di daerah penelitian dari tiga RW, yang berjumlah $54 \mathrm{KK}$, sedangkan untuk menentukan ukuran sampel RW dihitung dengan menggunakan rumus formula slovin, yaitu :

$\mathrm{n}=$ sampel;

$$
n=\frac{N}{1+N e^{2}}
$$

$\mathrm{N}=$ populasi;

$\mathrm{e}=$ Batas toleransikesalahan $=0,05$

Dari hasil perhitungan jumlah sampel, responden didapati menjadi 47 responden. Dari 47 sampel yang di dapat, penulis mengambilnya dengan cara di random. Adapun teknik analisa data hasil penelitian yang penulis gunakan adalah dengan teknik prosentase, degan formula:

$$
P=\frac{f}{N} x 100 \%
$$

Keterangan:

$p=$ Prosentase jawaban yang diperoleh 
$f=$ Frekuensi jawaban dari responden

$N=$ Pernyataan Responden sebagai sampel penelitian.

Adapun penafsiran kategori hasil penelitian adalah sebagai berikut:

Tabel 4. Rumus Prosentase

\begin{tabular}{cc}
\hline $0 \%$ & Tak seorang pun \\
\hline $1 \%-24 \%$ & Sebagian kecil \\
\hline $25 \%-49 \%$ & $\begin{array}{c}\text { Hampir } \\
\text { setengahnya }\end{array}$ \\
\hline $50 \%$ & Setengahnya \\
\hline $51 \%-74 \%$ & Sebagian besar \\
$75 \%-99 \%$ & $\begin{array}{c}\text { Hampir } \\
\text { seluruhnya }\end{array}$ \\
\hline $100 \%$ & Seluruhnya \\
\hline \multicolumn{3}{c}{ Sumber : Buku Metode Penelitian }
\end{tabular}

\section{HASIL DAN PEMBAHASAN}

\section{Lokasi Penelitian}

Desa Kolang, Kecamatan Kuwus Barat, Kabupaten Manggarai Barat, Flores-Nusa Tenggara Timur, merupakan sebuah desa yang terletak dibagian barat Provinsi Nusa Tenggara Timur. Desa Kolang terletak pada $7.0579821^{0}$ Lintang Selatan, $107.7509195^{\circ}$ Bujur Timur memiliki luas wilayah $\pm 10,4$ $\mathrm{km}^{2}$. Secara administratif terdiri dari 3 dusun dengan jumlah 9 RW dengan rincian Dusun Kolang 4 RW, Dusun Lenga 3 RW dan Dusun Ndong 2 RW. Batas wilayah Desa Kolang, Kecamatan Kuwus Barat, Kabupaten Manggarai Barat, Provinsi Nusa Tenggara Timur yaitu sebagai berikut

a. Bagian barat Berbatasan dengan Desa Sampang Kuwus

b. Bagian Timur berbatasan dengan Desa Rangga.

c. Bagian Utara dengan Desa Ndajur,

d. dan bagian Selatan berpatasan dengan Desa Sampang Suka.

Luas wilayah desa kolang berdasarkan penggunaannya pada tahun 2018 dapat kita lihat pada tabel 5 berikut:

Tabel 5. Luas Wilayah Berdasarkan Penggunaannya

\begin{tabular}{ll}
\hline Luas pemukiman & $8,5 \mathrm{ha} / \mathrm{m} 2$ \\
\hline Luas persawahan & $100 \mathrm{ha} / \mathrm{m} 2$ \\
\hline Luas perkebunan & $152 \mathrm{ha} / \mathrm{m} 2$ \\
\hline Luas kuburan & $4,5 \mathrm{ha} / \mathrm{m} 2$ \\
\hline Luas taman & $4 \mathrm{ha} / \mathrm{m} 2$ \\
\hline
\end{tabular}

total luas 270,ha/m2

Sumber: monografi Desa Kolang tahun 2018

\section{Kondisi Fisik}

Pada umumnya di Manggarai Barat Provinsi Nusa Tenggara Timur memiliki iklim yang sama, yaitu beriklim panas dengan suhu udara berkisar $17^{\circ} \mathrm{c}-32^{\circ} \mathrm{c}$. untuk Desa Kolang sendiri suhu rata-rata hariannya mencapai $30^{\circ} \mathrm{c}$. Sementara tinggi tempat dari permukaan laut mencapai $800 \mathrm{mdl}$. Pada umumnya di Desa Kolang, Kecamatan Kuwus Barat, kabupaten Manggarai Barat mempunya bentuk morfologi mulai dari yang datar atau landai, berbukit, sampai daerah pegunungan.

Desa Kolang kecamatan Kuwus Barat memiliki potensi hidrologi sumber daya air yang cukup, air yang ada di Desa Kolang bersumber dari air di bawah tanah maupun air permukaan. Air permukaan pada umumnya untuk digunakan memenuhi kebutuhan pertanian, air di dalam tanah untuk di gunakan kebutan rumah tangga.

Desa Kolang merupakan daerah yang memiliki curah hujan dengan kategori yaitu $150 \mathrm{~mm}$. Dengan jumlah bulan hujan 3 kali dalam 1 tahun. Secara umum Keadaan tanah di Kuwus barat Kabupaten Manggarai Barat sebagian besar mempunyai kondisi pertanahan yang bagus, berupa tanah hitam yang lebih subur dibandingkan dengan tanah pada umumnya, oleh karena itu sebagian besar warga Desa Kolang memanfaatkan lahan tersebut sebagai sektor untuk pertanian,

Penggunaan tanah di Desa Kolang di bagi kedalam tiga bagian yaitu, penggunaan tanah sawah, penggunaan tanah kering, dan penggunaan tanah perkebunan. Dari tiga penggunaan tanah tersebut, yang paling banyak di gunakan adalah penggunaan tanah kering, dengan rincian penggunaan tanah tegal/ladang mencapai $425 \mathrm{ha} / \mathrm{m} 2$, perkarangan $8,5 \mathrm{ha} / \mathrm{m} 2$ dan untuk pemukiman $4 \mathrm{ha} / \mathrm{m} 2$ sedangkan untuk penggunaan tanah perkebunaan perorangaan mencapai, $152 \mathrm{ha} / \mathrm{m} 2$, dan penggunaan tanah sawah yaitu digunakan untuk sawah tadah hujan $100 \mathrm{ha} / \mathrm{m} 2$. 
Kristiano, R., Suryana., Supriatna, U. Perkembangan Sarana dan Prasarana Transportasi... 136

\section{Kondisi Sosial Masyarakat}

Penduduk Desa Kolang Kecamatan Kuwus Barat Kabupaten Manggarai Barat Provinsi Nusa Tenggara Timur dengan jumlah penduduk tahun 2018 sebanyak 1 . 238 jiwa, terbagi 230 kepala keluarga; 602 orang laki-laki dan 636 orang perempuan. Secara terperinci dapat kita lihat Komposisi penduduk di Desa Kolang Kecamatan Kuwus Barat Kabupaten Manggarai Barat Provinsi Nusa Tenggara Timur berdasarkan Usia (tabel 6), berdasarkan Jenis Kelamin (tabel 7), Agama (tabel 8), dan berdasarkan Mata Pencaharian (tabel 9).

Tabel 6. Jumlah Penduduk Bedasarkan usia

\begin{tabular}{cc}
\hline Menurut Usia & Jumlah \\
\hline $0-5$ & 131 \\
\hline $6-10$ & 134 \\
\hline $11-15$ & 142 \\
\hline $16-20$ & 113 \\
\hline $21-25$ & 108 \\
\hline $26-30$ & 92 \\
\hline $31-35$ & 84 \\
\hline $36-40$ & 72 \\
\hline $41-45$ & 98 \\
\hline $46-50$ & 31 \\
\hline $51-55$ & 58 \\
\hline $56-60$ & 57 \\
\hline $61-$ keatas & 90 \\
\hline Total Jumlah & 1238 \\
\hline Sumber : Monografi Desa Kolang thn 2018
\end{tabular}

Komposisi penduduk berdasarkan umur pada tahun 2018 , sebagain besar penduduk tergolong pada usia 11-15 tahun sebanyak 142 orang.

Tabel 7. Populasi Orang

\begin{tabular}{clcccc}
\hline \multirow{2}{*}{ Ro } & RW & \multicolumn{4}{c}{ Penduduk } \\
\cline { 3 - 6 } & & Pria & Wanita & Jumlah & KK \\
\hline 1 & 1 & 107 & 127 & 234 & 46 \\
& kolang & & & & \\
\hline 2 & $\begin{array}{l}2 \\
\text { kolang }\end{array}$ & 74 & 78 & 152 & 28 \\
\hline 3 & $\begin{array}{l}3 \\
\text { kolang }\end{array}$ & 38 & 43 & 81 & 15 \\
\hline 4 & $\begin{array}{l}4 \\
\text { kolang }\end{array}$ & 55 & 42 & 97 & 15 \\
\hline 5 & 5 & 41 & 43 & 84 & 16 \\
\hline
\end{tabular}

\begin{tabular}{|c|c|c|c|c|c|}
\hline & kolang & & & & \\
\hline 6 & $\begin{array}{l}6 \\
\text { lengan }\end{array}$ & 81 & 85 & 166 & 31 \\
\hline 7 & $\begin{array}{l}7 \\
\text { lenga }\end{array}$ & 67 & 71 & 138 & 26 \\
\hline 8 & $\begin{array}{l}8 \\
\text { ndong }\end{array}$ & 80 & 85 & 165 & 30 \\
\hline 9 & $\begin{array}{l}9 \\
\text { ndong }\end{array}$ & 58 & 62 & 121 & 23 \\
\hline & Total & 602 & 636 & 1238 & 230 \\
\hline
\end{tabular}

Tabel 8. Keadaan Penduduk Berdasarkan Agama

\begin{tabular}{cc}
\hline $\begin{array}{c}\text { Penduduk Menurut } \\
\text { Agama }\end{array}$ & Jumlah \\
\hline Islam & - \\
\hline Katolik & 1238 \\
\hline Hindu & - \\
\hline Budha & - \\
\hline Prostestan & - \\
\hline Sumber : Monografi Desa Kolang Thn 2018
\end{tabular}

Dari keterangan tabel 8 mentakan bahwa masyarakat Desa Kolang pada umumnya Menganut Agama Katolik yang berjumlah 1238, sedangkan keadaan penduduk untuk kategori mata pencaharian di desa kolang terbagi dengan beberapa kategori, untuk lebih detail dapat kita lihat pada tabel 9.

Tabel 9. Jumlah Penduduk Berdasarkan Pekerjaan

\begin{tabular}{lccc}
\hline \multicolumn{1}{c}{$\begin{array}{c}\text { Mata } \\
\text { Pencaharian }\end{array}$} & L & P & Jumlah \\
\hline Tani & 509 & 167 & 676 \\
\hline Nelayaan & - & - & \\
\hline Dagang & 7 & - & 7 \\
\hline Sopir & 4 & - & 4 \\
\hline Buruh & - & - & \\
\hline Pns & 3 & 2 & 5 \\
\hline Tni & - & - & \\
\hline Polri & - & - & \\
\hline Swasta & - & - & \\
\hline Total & & & 692 \\
Jumlah & & \\
\hline
\end{tabular}

Sumber: Monografi Desa Kolang 2018

Berdasarkan pekerjaan masyarakat di dominan dengan masyarakat Desa Kolang 
Kecamatan Kuwus Barat Kabupaten Manggarai Barat Provinsi Nusa Tenggara Timur yang bekerja sebagai petani yang berjumlah 676 orang, sopir 4 orang dan PNS 5 orang. Dan yang bekerja sebagai pedagang 7 orang.

\section{Analisis Hasil Penelitian}

Berdasarkan data dan informasi yang penulis dapatkan dari hasil wawancara, penyebaran angket, serta dokumentasi, tentang Perkembangan Sarana Dan Prasarana Transportasi Dalam Hubungannya Dengan Tingkat Perekonomian Masyarakat Di Desa Kolang, Kecamatan Kuwus Barat, Kabupaten Manggarai Barat, Provinsi Nusa Tenggara Timur, Penyedian sarana dan prasarana transportasi yang baik akan mempermudah masyarakat dalam melakukan mobilisasi baik orang maupun barang. Adapun permasalahan yang di pengaruhi oleh sarana dan prasrana transportasi yaitu tingkat pendidikan, pendapatan, keterjangkauan atau jarak, mata pencaharian, biaya transportasi, penggunaan kendaraan.

Tabel 10. Pengaruh Sarana dan Prasarana transportasi yang rusak terhadap pendapatan masyarakat

\begin{tabular}{|c|c|c|c|}
\hline \multirow[b]{2}{*}{ No } & \multirow[b]{2}{*}{ Keterangan } & \multicolumn{2}{|c|}{ Frekuensi } \\
\hline & & $\begin{array}{c}\text { Jumlah } \\
\text { Responde } \\
\mathrm{n}\end{array}$ & $\%$ \\
\hline 1 & $\begin{array}{c}\text { Tidak } \\
\text { mempengaruh }\end{array}$ & - & \\
\hline 2 & $\begin{array}{c}\text { Sangat } \\
\text { mempengaruhi }\end{array}$ & $\begin{array}{c}47 \\
\text { orang }\end{array}$ & $\begin{array}{c}100 \\
\%\end{array}$ \\
\hline & Jumlah & 47 & 100 \\
\hline
\end{tabular}

Tanggapan masyarakat terhadap pengaruh sarana dan prasarana transportasi yang rusak terhadadap peningkatan pendapatan ekonomi masyarakat di Desa Kolang, dari 47 sampel yang di ambil, besar jawabanya mencapai $100 \%$ bahwa dimana sarana dan prasarna transportasi sangat mempengaruhi sekali terhadap pendapatan mereka. Di lihat dari tanggapan masyarakat, kita tahu bahwa dimana sarana dan prasarna transportasi yang kurang membaik akan berpengaruh terhadap pendapat di suatu wilayah.

Berdasarkan hasil penyebaran angket yang penulis telah sebarkan tingkat pendidikan masyarakat dari $3 \mathrm{RW}$ di Desa Kolang dapat kita lihat pada tabel berikut ini:

Tabel 11. Tingkat Pendidikan Responden

\begin{tabular}{|c|c|c|c|}
\hline \multirow[b]{2}{*}{ No } & \multirow{2}{*}{$\begin{array}{c}\text { Jenis } \\
\text { Pendidikan }\end{array}$} & \multicolumn{2}{|c|}{ Frekuensi } \\
\hline & & $\begin{array}{c}\text { Jumlah } \\
\text { Responden }\end{array}$ & $\%$ \\
\hline 1 & SD & 18 & $\begin{array}{c}38,29 \\
\%\end{array}$ \\
\hline 2 & SMP & 11 & $\begin{array}{c}23,40 \\
\%\end{array}$ \\
\hline 3 & SMA & 12 & $27,65 \%$ \\
\hline 4 & $\mathrm{~S} 1$ & 2 & $2,12 \%$ \\
\hline 5 & $\mathrm{~S} 2$ & - & \\
\hline 6 & S3 & - & \\
\hline 7 & $\begin{array}{c}\text { Tidak } \\
\text { Berpendidikan }\end{array}$ & 4 & $8,51 \%$ \\
\hline & Jumlah & 47 & 100 \\
\hline
\end{tabular}

Angka tingkat pendidikan Responden yang ada di Desa Kolang masih rendah, yaitu 38\% tingkat Pendidikan sekolah Dasar (SD) sementara Sekolah Menengah Pertama (SMP) 23\%, Sekolah Menengah Atas (SMA) 27\%, dan Sarjana (S1) hanya $2 \%$, serta adapun yang tidak berpendidikan sebesar $8 \%$. Oleh karena, itu diharapkan untuk pemerintah setempat kususnya yang ada di Manggarai Barat, melakukan penyuluhan kepada masyarakat tentang bagaimana pentingnya pendidikan di masa sekarang, atau pemerintah bisa membuka peluang kursus bagi masyarakat, agar mereka juga memiliki keterampilan sebagaimana yang dimiliki oleh para pendidik. 
Tabel 12. Berdasarkan tingkat pekerjaan penduduk

\begin{tabular}{cccc}
\hline \multirow{2}{*}{ No } & \multirow{2}{*}{ Options } & \multicolumn{2}{c}{ Jumlah } \\
\cline { 3 - 4 } & & Frekuensi & $\%$ \\
\hline 1 & Petani & 40 & $85,10 \%$ \\
\hline 2 & Pedagang & 1 & $2,12 \%$ \\
\hline 3 & PNS & 2 & $4,25 \%$ \\
\hline 4 & Pengangguran & 4 & $8,51 \%$ \\
\hline & Jumlah & 47 & 100 \\
\hline
\end{tabular}

Tabel 12, menunjukan bahwa tingkat pekerjaan penduduk di Desa Kolang $85,10 \%$ sebagian besar merupakan petani, $2,12 \%$ bekerja sebagai pedagang, sementara $4 \%$ sebagai PNS, dan pengangurannya $8 \%$.

Tabel 13. Biaya transportasi

\begin{tabular}{cccc}
\hline \multirow{2}{*}{ No } & Options & $\begin{array}{c}\text { Jumlah } \\
\text { Responen }\end{array}$ & \\
\hline \multirow{2}{*}{1} & $\begin{array}{l}50.000- \\
100.000\end{array}$ & - & \\
\hline 2 & $\begin{array}{l}100.000- \\
1.50 .000\end{array}$ & 47 & $100 \%$ \\
\hline 3 & $\begin{array}{l}1.50 .000- \\
2.000 .000\end{array}$ & - & \\
\hline 4 & $\begin{array}{l}\text { Lebih dari } \\
2.000 .000 .\end{array}$ & - & \\
\hline & Jumlah & 47 & 100 \\
\hline
\end{tabular}

Tabel di atas, menunjukkan biaya transportasi yang dikeluarkan masyarakat Kolang untuk menuju kota mencapai Rp 100.000,- - Rp 1.50.000,-. tidak termasuk dengan ongkos pulangnya, dan transportasi yang dari daerah Kolang hanya satu kali jalan. Kondisi tersebut disebabkan kerena jarak yang lumayan jauh jalan yang rusak.

\section{Pembahasan Hasil Penelitian}

Berdasarkan hasil penelitian penulis membuat penafsiran hasil penelitian tentang "Perkembangan Sarana dan Prasarana Transportasi Dalam Hubungannya dengan Tingkat Perekonomian Masyarakat Desa Kolang, Kecamatan Kuwus Barat, Kabupaten Manggarai Barat, Provinsi Nusa Tenggara Timur"
Sarana dan prasarana transportasi memiliki beberapa dampak yang secara langsung maupun tidak langsung dimasyarakat. Ketersedian dan lancarnya sarana dan prasarana transportasi mampu menghapuskan suatu daerah yang terisolasi, serta aksebilitaspun meningkat. Peningkatan ini membuka suatu peradaban yang baru bagi daerah pedesaan tersebut, sehingga kemajuan dan moderenisasi yang berasal dari daerah pusat pemerintah dapat dengan mudah masuk ke daerah pedesaan. Transportasi darat menjadi salah satu moda. Transportasi tidak dapat dipisahkan dari moda-moda transportasi lainnya.. Salah satu prasarana transportasi yang sangat penting dikembangkan adalah jalan raya. Keberadaan dan kualitas jalan yang baik akan sangat mendukung upaya percepatan pembangunan daerah. Hal ini dapat dilihat dari segi ekonomi, yang mana dengan lancarnya sarana transportasi, pemasaran hasil usahapun semakin mudah. Penyediaan transportasi yang baik mampu menciptakan pasar dan penyedian sarana produksi pertanian atau sarana produksi suatu usaha.

Sistem sarana dan prasarana transportasi yang ada bermanfaat untuk meningkatkan pelayanan mobilisasi penduduk dan sumber daya lainya yang dapat mendukung pertumbuhan ekonomi di daerah ini. Kondisi ini menyebabkan pengurangan tenaga kerja yang mempunyai keahliaan dan keterampilan pada wilayah tertentu, selain itu sarana dan prasarana transportasi juga membuka peluang untuk kegiatan perdagangan antar wilayah. Keberadaan sarana dan prasarana transportasi yang baik dapat menghilangkan sifat terisolasi dan memberikan stimulasi ke arah perkembangan di semua bidang kehidupan, baik perdagangan ,maupun sektor lainnya.

\section{SIMPULAN}

Berdasarkan hasil penelitian Perkembangan Sarana dan Prasarana Transportasi terhadap peningkatan Ekonomi masyarakat di Desa Kolang, Kecamatan Kuwus Barat, Kabupaten Manggarai Barat, Provinsi Nusa Tenggara Timur. Maka peneliti dapat menarik kesimpulannya sebagai berikut : 
Bahwa Sarana dan prasarana transportasi merupakan modal utama dalam mengembangkan suatu daerah, dimana peran transportasi sangat di perlukan masyarakat untuk melakukan aktivitas sehari-hari. Transportasi juga merupakan bagian utama dari proses produksi barang dan jasa yang akan memberikan kontribusi manfaat yang besar terhadap pertumbuhan ekonomi, mengurangi kemiskinan dan kesinambungan lingkungan. Transportasi darat menjadi salah satu moda, transportasi tidak dapat dipisahkan dari moda-moda transportasi lain yang ditata dalam sistem transportasi nasional yang dinamis dan mampu beradaptasi dengan kemajuan dimasa depan.

Keberhasilan pembangunan sangat di pengaruhi oleh peran transportasi sebagai urat nadi kehidupan politik, ekonomi, sosial budaya, dan pertahanan keamanan. Pembangunan sektor transportasi diarahkan pada terwujudnya sistem transportasi nasional yang handal, berkemampuan tinggi dan di selenggarakan secara efektif dan efisien dalam menunjang dan sekaligus menggerakan dinamika pembangunan, mendukung mobilisasi manusia, barang serta jasa, mendukung pola distribusi nasional serta mendukung pengembangan wilayah dan peningkatan hubungan internasional yang lebih membawa pada perkembangan kehidupan berbangsa dan bernegara dalam rangka perwujudtan wawasan nusantara.

\section{REKOMENDASI}

Beradasarkan pada hasil penelitian yang telah dilakukan dan upaya menganalisis berbagai persoalan yang muncul, serta pertimbangan- pertimbangan berdasarkan penyimpulan hasil kajian permasalahan, maka ada bebarapa saran untuk di tindak lanjuti sebagai implikasi dari penelitian ini. Ada pun saran- saran tersebut yaitu harapan peneliti selanjutnya di Desa Kolang, supaya tidak hanya meneliti masalah pengaruh sarana dan prasarana transportasi terhadap tingkat perekonomian masyarakat. Tapi peneliti yang sekarang mengharapkan agar mencari lebih dalam lagi masalah apa saja yang mempengaruhi tingkat ekonomi di Desa Kolang .

\section{DAFTAR PUSTAKA}

Abdurachmat, Idris dan Maryati, E. (1997). Geografi Ekonomi. FPIPS IKIP: Bandung.

Ahmada Erani Yustika. (2016). Sarana dan Prasarana Transportasi Desa. Kompak: Jakarta.

Arikunto, Suharsimi. (1996). Prosedur Penelitian Suatu Pendekatan Praktek. Rineka Cipta: Jakarta.

Adriansyah. (2015). Manajemen Transportasi Dalam Kajian dan Teori. Kompak: Jakarta.

Arikunto. (1993). Prosedur Penelitian. Rineka Cipta: Jakarta.

Berkas Pemerintah Daerah. (2018). Monografi Desa Kolang Kecamatan Kuwus Barat Kabupaten Manggarai Barat Provinsi Nusa Tenggara Timur. Pemda: Manggarai Barat

Bintarto, R. dan Hadisumarno, Surastopo. (1991) 1991. Metode Analisa Geografi, LP3ES (Lembaga Penelitian, Pendidikan dan Penerangan Ekonomi dan Sosial): Jakarta .

Gunarto.R.B. 2014. Geografi Trasnpportasi. Ombak: Yogyakart.

Penelitian Deskriptif. http://ayo-nambahilmu.blogspot.com/2016/06/meotdepenelitian-deskriptif-jenis.htm 1 ?m=1 diakses pada 22 Maret 2019.

Rafi'i, Suryatna., 1986. Metode Statistika Analisis. Bina Cipta: Bandung. 
Ruseffendi, E.T. 1994. Pengantar Penelitian Bidang Non-Eksakta Lainnya. Tarsito: Bandung.

Syahrum Dan Salim. 2012. Metodologi Penelitian Kuantatif. Cipustaka Media: Bandung.
Surachmad, Winarno. 1980. Pengantar Penyelidikan Ilmiah. Tarsito: Bandung.

Singarimbun, Masri. 1989. Metode-Metode Penelitian Survei. LP3ES (Lembaga Penelitian, Pendidikan dan Penerangan Ekonomi dan Sosial): Jakarta. 